\title{
Islamic Finance for Sustainable Micro-Finance Development in Indonesia
}

\author{
Iskandar \\ Department of Sharia and Islamic Economics \\ IAIN Syaikh Abdurrahman Siddik \\ Bangka Belitung, Indonesia \\ iskandar@iainsasbabel.ac.id
}

\begin{abstract}
Micro and small enterprises are the back bone of Indonesian economy. For that condition, the availability of financial inclusion system is needed to prop up the economic increase. In Islamic Financial System, islamic pawn as a tabarru' contract has inclusive characteric if developed by a flexible model that commite to principles of shariah. For example, created Islamic pawn based on formal property system.
\end{abstract}

Keywords: AEC, Financial Inclusion, Islamic Pawnshop, Micro And Small Enterprises

\section{INTRODUCTION}

Currently, Bank Indonesia is working to strengthen the MSME sector as a consequence of monetary policy that demands economic stability is maintained. BI has created several MSME clusters and provided data on their development, as can be seen on the official BI website. This policy was also followed by the launch of a branchless system or an officeless banking system. The main goal is to be able to reach the capital needs of people in the area or small villages. On the other hand, BPS data shows that $99.9 \%$ of the Indonesian economy is supported by the MSME sector, not UB (Big Business).

According to Tulus Tambunan, Micro, Small and Medium Enterprises (MSMEs) play an important role in development and economic growth, not only in developing countries, but also in developed countries (Tambunan, 2012). That is, the weakening of MSME growth is an indication of a country's economic fragility. At this point, Indonesia's position as a developing country has enormous power in the MSME sector. Indonesia's expansive pyramid type of population where most of the population is in the young or productive age group requires the availability of employment that absorbs a lot of labor. Moreover, Indonesia's poverty and unemployment rates are still very high. Based on BPS data, as of September 2012 recorded $11.66 \%$ or equivalent to 28.59 million. The number of open unemployment until August 2012 was $6.14 \%$ or around 7,244,956 (BPS: 2013).

Then how does the offer of Islamic economics answer the problem? As is commonly understood, Islamic economics is very firm in stating the prohibition of interest, gambling, corruption, and encouraging economic activities that are truly based on the real sector (M. Luthfi Hamidi: 2012). Money in the concept of Islamic macroeconomics is a flow concept not a stock concept. This means that the actual economic growth will be realized if there is a 'flow of money' to the real sector.
Capital is private, while money is public goods, as written by Adiwarman Karim (2007).

The derivation of the concept of money is the existence of a financial system that is friendly to the real sector. Mudharabah, murabahah, musharaka, etc. agreements are aimed at sustaining the real sector. In shari'ah banking practices it is clearly stated that the vision of the development of sharia banking in Indonesia is "the realization of a competitive, efficient sharia banking system that meets the principle of prudence that is able to support the real sector in real terms through profit-sharing based financing activities (share based financing) and real transactions within the framework of justice, please help and towards the good in order to achieve the benefit of the community. " (DPS: 2002)

This paper focuses on two things, namely revealing sharia financial exclusive practices and how to reconstruct them to be more inclusive and equitable. The shari'ah financial instrument used as the unit of analysis is the syari'ah pawn (rahn / Islamic pawnbroking) which is a socially oriented contract (tabarru ') but has an inclusive nature for the development of MSEs.

\section{CRITICISM OF Sharia Financial Practices}

The rate of development and economic growth, demands the availability of financial services that are inclusive. This is intended so that the benefits of development, namely welfare, are not only enjoyed by certain groups of people, wealthy groups, while for the lower middle class it experiences the opposite condition. Inequality in development shows that the nature of economic growth is only concentrated in quantitative quantities, but does not pay much attention to the quality of development itself. The impact is the distribution of uneven development, and is accompanied by high unemployment and poverty. In such conditions, development seems to be an exclusive right for the rich.

These problems can be answered, including by formulating an inclusive financial system. Namely, a financial service system that is open to all groups, especially providing easy access to finance or capital for micro and small groups or the poor and low-income groups (Nusron Wahid: 2014). It is intended that the fundamentals of economic development become stronger by increasing and strengthening the role of MSMEs (Tambunan: 2012). As is known, the main problem of micro and small businesses is related to the availability of capital. In general, they do not have access to financial institutions because they do not have legal assets that can be 
used as collateral. For this reason, not a few micro and small entrepreneurs depend their business capital on moneylenders who provide capital facilities without collateral.

This condition certainly raises the question of how Islamic financial institutions answer the issue. Viewed from a theoretical aspect, the concept of shari'ah finance is basically inclusive. This claim starts from its main foundation, namely "so that assets (capital) do not revolve between a group of people (rich) only. This is also in line with the basic concepts of shari'ah finance as explained in various fiqh mu'amalah books. Not only Tabarru contracts', tijari agreements are also intended to allow capital distribution to groups that need capital to drive their business. It can also be a means to strengthen the efforts that have been made, so as to increase the value of benefits, both material and non-material benefits or social benefits.

Tabarru contract 'or gratuitous contract can be said expressly as a form of agreement that has a social dimension or non-profit transaction, so it should not be used as a mode of profit making. Tabarru 'means kindness, therefore this contract is made for the purpose of helping in doing good. Those who do good, therefore, are not entitled to require any compensation to other parties (Adiwarman A. Karim, 2013). However, the party may request that the counter-parts only cover the costs (cover the cost) incurred for the implementation of the contract.

On the other hand, the tijari agreement is intended so that the parties in the agreement can take advantage of the transactions made. In general, this contract can be divided into two, namely based on the principle of exchange, such as the murabahah, salam, istisna ', ijarah; or based on the principle of mixing, such as the musyarakah contract, muzara'ah, mudharabah, musaqah, mukhabarah. If explored more deeply, and without ordinating the spirit of seeking profit, these two categories of contract encourage the spirit of capital distribution to various parties. If the party that is committed is a group that already has capital, then it can be a means to strengthen the business that is being developed. On the other hand, if it is channeled to those who lack capital or to the MSE sector, then it becomes a means to strengthen the economic foundation of the lower middle class community. This character is the foundation of the inclusive nature of Islamic finance.

The question then is whether at a practical level, Islamic finance is able to be inclusive, so that it absorbs all levels of society, especially as a service provider for venture capital needs? The answer to this question is very important as a logical basis for criticism of the implementation of the syari'ah pawn system in Indonesia. In the development of syari'ah finance, the syari'ah pawn system is valued by many parties as a model of microfinance services to support microeconomic activities, especially for the Micro and Small Business groups. At this point, the critical step towards the developing syari'ah pawn system is intended to reconstruct a more equitable pattern of development of the syari'ah pawn; namely being able to revive the micro sector, in addition to also providing benefits to the Shari'ah mortgage service business itself.

Shari'ah finance that moves directly to the MSE sector is the Syari'ah Financial Services Cooperative or Batiul al-Mal wa al-Tamwil. This financial institution has developed in such a way, providing financial services, both capital financing, consumption, investment, and also savings. However, in its development, KJKS or BMT, faced various fundamental problems, especially the weak commitment of this institution to the principles of shari'ah itself. The impact, the image of this institution is not so good, because it is considered as "Bank Eating Friends" which in Bagus Arya language is called "sinking into the flow of neoliberalism" (Bagus Aryo: 2012).

Hope is supported by the UMK sharia financial institutions, then it depends on sharia banking. Because, insurance institutions, mutual funds, capital markets, and so on, basically pay more attention to the upper middle class community. Basically, Islamic banking pays full attention to efforts to move the real sector, especially those engaged in the MSE sector. This is stated firmly in the vision of sharia banking.

However, the main problem faced by Islamic banks in opening access to capital for the group is related to the absence of collateral for financing, a high enough risk value that is considered to threaten the health of banks, and pragmatic insistence that Islamic banking is able to strengthen the market share. For this purpose, Islamic banks use many murabaha schemes compared to more inclusive schemes, such as mudaraba and musharaka (Malik \& Wahyuni: 2013; Arianto: 2011). Moving on from this obstacle, it is very natural that in the eyes of small communities engaged in the MSE sector, sharia banking is still less prestigious than "plecit bank". In fact, these various problems can be covered by channeling qardhul hasan funds which basically will not interfere with the health of banks, on the contrary it can improve the image or good will of sharia banking (Adnan \& Furywardhana: 2006).

In fact, when referring to sharia banking statistics in 2013, the portion of financing disbursed by BUS and UUS is more focused on the Small and Medium Enterprises (SMEs) group compared to other or Large Enterprises. However, judging from the scheme that is used, basically those who are touched by Shari'ah financial services are the Medium Enterprises group, considering that this group has bankable assets so that they can be used as collateral for financing. Conversely, assets owned by micro and small groups are generally considered not bankable. This condition, is seen with the decreasing portion of financing to SMEs from 2014 to 2015 . In fact, the ratio of non-current financing to the two business groups is very small, where UB's non-current financing is greater than that of UKM, which are 5,308 compared to 4,003 billion. That is, the rate of return on financing from SMEs is slightly higher when compared to other businesses (OJK: 2015).

\section{THE IMPORTANCE OF COMMITMENT TO SHARIA PRINCIPLES AS THE BASIS FOR INCLUSIVE FINANCE}

Since the spirit of islamization has been echoed and in the past three decades sharia financial institutions have grown and developed, many have questioned whether the expression of that spirit has been in line with the basic principles of the shari'ah itself (Yusdani: 2007). Hossein Askari and Scheherazade S. Rehman, for example, indexed the Islamic level of the so-called "Islamic" countries (Rehman \& Askari: 2010). As a result, none of the countries claimed to be "Islamic" fully committed to carrying out Islamic values. Conversely, Islamic values are precisely found in countries where the majority of the population is non-Muslim, such as New Zealand, Luxembourg and Ireland. Of the 56 OIC countries, the highest scores were Malaysia (38th), Kuwait 
(48), United Arab Emirates (66), Morocco (119), Saudi Arabia (131), Pakistan (147), Yemen (198), and worst is Somalia (206). Western countries that are judged to be close to Islamic values are Canada at number 7, Britain (8), Australia (9), and the United States (25). Indonesia itself in the assessment of the two researchers is ranked 140th. That is, there are big questions that must be answered that the 'Islamic' claim must be followed by a commitment to carry out the basic principles of sharia values as confirmed by Ibn Qayyim as follows:

Sharia is based on wisdom and achiving people's life in this life and the afterlife. Sharia is all about justice, mercy, wisdom, and good. Thus, any ruling that replaces justice with justice, mercy with its opposite, common good with mischief, or wisdom with nonsense, is a ruling that does not belong to the shariah, even if it is claimed to be according to some interpretation, " thus quoted by Jasser Auda (Jasser Auda: 2007).

Admittedly, the results of Hossein's and Rehman's research, as confirmed by Komaruddin Hidayat, naturally leave many serious questions that need to be answered through comparable research. If a Muslim society or country is corrupt and repressive, is this error caused more by the behavior of the people or the government system? Or is it due to the wrong Islamic education system and culture? However, one thing is certain, this study concludes that social, economic, and political behavior of OIC member countries are even further away from Islamic teachings than non-Muslim countries whose behavior is more Islamic (Hidayat: 2011).

Apart from these problems, more specific questions can be asked relating to the spirit of the development of Islamic financial institutions. The question is whether sharia financial institutions are in line with sharia principles? Is the Islamic bank Islamic? There are at least three forms of answers to this question, namely: critical, skeptical, and pragmatic. The following explanation!

Groups that use a critical approach consider the existence and development of sharia financial institutions as a form of political movement that is trapped in market reason and becomes a new variant of capitalism. Sharia bank operations, for example, are unable to commit to implementing sharia principles, such as applying the concept of profit and loss sharing properly and correctly. On the other hand, it is precisely just exchanging the term "interest" with murabaha margins which are considered mathematically more burdensome to customers than interest at conventional banks. In other words, the existence of Islamic banks is an effort to "Islamize Capitalism" (Hefner: 1999; Saeed: 1996). Even so, this group does not reject the existence of Islamic banks as a historical fact that is currently highlighted by many parties.

For skeptics, starting with the assumption that the concept of usury understood by academics and practitioners of Islamic financial institutions has been mistaken. This is due to the fact that the institutions which are labeled sharia still use paper money. In fact, according to skeptics, paper money is usury that must be denied its existence. The use of banknotes is nothing more than the usury empowerment movement. Therefore, according to them sharia banks are non-sharia banks. In other words, as long as they still use paper money, whatever institution is a usury institution and not sharia. As a solution, there must be a movement back to the dinar and dirham (Vadillo: 2005; Saidi: 2005, 2007, 2010).

As for pragmatic or mainstream groups, the growth and development of sharia banks must be viewed positively. The basic concepts of fiqh mu'amalah Maliyah, are not yet fully applied properly and correctly. For this reason, strategic steps are needed to realize the expected ideal conditions. These strategic steps, for example, relate to targets that must be achieved within a certain time frame. In other words, weaknesses in the operations of Islamic financial institutions are not used as a reason to judge negatively or lead to skepticism. Nevertheless, the dialectics between these three groups actually makes the effort to develop worksheets more directed to the idealized concept.

From the three aspects and perspectives, it can be understood that the efforts to develop LKS are still not fully committed to implementing sharia principles. The pragmatism perspective, despite its many weaknesses, can be understood as a strategic step which is considered by some parties as the most appropriate policy in dealing with market demands. Therefore, commitment to sharia principles experiences a narrowing of meaning as an institution that is free of interest.

\section{RAHN; TABARRU AGREEMENT 'FOR INCLUSIVE FINANCE}

The principle of inclusive finance, theoretically comes from several theories of political economy, such as: modernization theory, investment theory, human capital theory, and behavior theory. Seen from the point of view of modernization theory, poverty alleviation efforts are rooted in efforts to provide capital. That is, the principle of inclusive finance is to encourage the availability of access to capital for the poor to develop independent businesses. At this point, modernization theory is in line with investment theory which asserts that the phenomenon of poverty is caused by the low amount of capital invested. In other words, through financial inclusion, it is possible for low-income poor people to get capital injections, which are first made possible by reducing the collateral burden and the cost of repaying loans (Wahid: 2014).

Furthermore, based on the theory of human capital, humans are said to need access to financial institutions to get business credit in order to increase their capacity. For this reason, everyone needs to get the same opportunity to financial institutions in order to get costs that can be used to increase their human capital. According to behavior theory (firm behavior theory), financial inclusion schemes are proven to have external effects that are able to cut costs in the business world. Empirically, efficiency encourages increased productivity and the creation of new job opportunities (Wahid: 2014).

Based on these theories, the basic principle of inclusive finance is an effort to create a financial system that provides easy access, networking into the formal financial sector, as well as reducing costs for the lower middle class. The aim is to overcome poverty, thereby increasing the benefit of people's lives in general. Therefore, in the context of the formulation of an inclusive sharia pawn scheme, it is very important to pay attention to these basic principles.

Schemes that can be developed to develop sharia liens as an alternative model for financial inclusion are formal property system schemes. The aim is to create an inclusive 
Shari'ah mortgage format. The emphasis is that the poor have legality over their wealth. Why is that?

According to Nusron Wahid, there are nine obstacles that must be faced to create an inclusive financial system. Namely: 1) impartial policy; 2) poor supporting infrastructure in the banking world; 3 ) the scarcity of an adequate data collection system, which includes identity data, proof of residency, reference letters, and other documents; 4) insufficient public knowledge about the financial world; 5) high costs for opening a savings account or just to check savings; 6) poor technology infrastructure to utilize the financial system; 7) low income; 8 ) the scarcity of financial services products that are suitable for reaching the poor into the formal system; 9) the high cost of financial services pegged by financial institutions (Wahid: 2014).

These barriers, seem to be the root of why Islamic financial institutions have not been able to massively be able to touch the lower middle class. In the case of syari'ah pawn, the gold pawning product seems very exclusive, because the ability to absorb customers of this product only touches the middle and upper classes. As for the lower middle class, it will be difficult to get capital because they do not have gold that can be mortgaged. On the other hand, it was also not touched by banking institutions because it was deemed not to meet the provisions of $5 \mathrm{C}$ which became the recipient of funding criteria.

\section{CONCLUSIONS}

The pawn system in Indonesia, has not yet become a fair pawning system. This is caused by legal factors that overlap competitiveness, community behavior that tends to adverse selection and default, and most importantly is due to the practice of ribawi which harms the pawners. The importance of a fair lien legal framework as a solution to this phenomenon is started by building a formal property system. With this system, it provides opportunities for micro and small groups to get capital through sharia financial services, even if they do not have gold. This is because with the existence of asset documents, micro and small community groups can easily access shari'ah pawn services. This can be applied by using various forms of contracts, such as mudaraba, bai'al-sharf, ijarah, qardhul hasan, and so on.

\section{REFERENCES}

[1] Al-Syathibi, Abu Ishaq, al-Muwafaqat fi Ushul alSyari'ah, Kairo : Maktabat wa Matba'at Muhammad Ali Sabih wa Auladih, 1969

[2] Aminuddin, "Posisi Pegadaian Syariah di Indonesia Berdasarkan Fatwa DSN-MUI Nomor 25 dan 26 Tahun 2002," al-Mawarid, Vol. XI., No. 1., Februari-Agustus 2010

[3] Asmuni Mth, "Teorisasi al-Maqashid: Upaya Pelacakan Historis," dalam Tim Penulis UII, Pribumisasi Hukum Islam Pembacaan Kontemporer Hukum Islam di Indonesia, Yogyakarta : Kaukaba, 2012

[4] Asmuni Mth. "Produk Perbankan Syariah; Antara alMinhaj al-Raddi dan al-Minhaj al-Maqashidi," alIslamiyah No. 1 Tahun XIX, Februari 2013

[5] Auda, Jasser, Maqashid al-Syari'ah as Philosophy of Islamic Law; a System Approach, London : IIIT, 2007
[6] Auda, Jasser, Magashid al-Syariah: A Beginner's Guide, London : IIIT, 2008

[7] Basyir, Ahmad Azhar, Hukum Islam tentang Riba, Hutang-Piutang, Gadai, Bandung : al-Ma'arif, 1975

[8] Fairooz, Mohammed, dkk., "Critical Appraisal of The Rahn-Based Islamic Microcredit Facility," Research Paper ISRA, No. 45, 2012

[9] Hardiman, F. Budi, Kritik Ideologi: Menyingkap Pertautan Pengetahuan dan Kepentingan Bersama Jurgen Habermas, Edisi Ketiga, Yogyakarta : Kanisius, 2009

[10] Haryanto, Budiman Setyo, "Kedudukan Gadai Syariah (Rahn) dalam Sistem Hukum Jaminan Indonesia," Jurnal Dinamika Hukum, Vol. 10, No. 1, 2010

[11] Hidayat, Komaruddin, Menafsirkan Kehendak Tuhan, Jakarta : Teraju, 2004

[12] Kamali, Mohammad Hashim, "Maqashid al-Syariah and Ijtihad as Instrument of Civilisational Renewal; a Methodological Perspective," ICR Pluto Jurnal, tth.

[13] Karim, Adiwarman A., Bank Islam Analisis Fiqh dan Keuangan, Jakarta : Rajawali Press, 2004

[14] Lahsana, Ahcene, Maqashid al-Syariah in Islamic Finance, Kuala Lumpur : IBFIM, 2013

[15] Manurung, Adler Haymans, Modal untuk Bisnis UKM, Panduan Mudah Mendapatkan Dana Perbankan, Pegadaian, Koperasi, Pasar Modal, Jakarta : Kompas, 2008

[16] Marhanita, Tinjauan Yuridis tentang Gadai Syariah di Kantor Pegadaian Syariah Lhokseumawe, Tesis, Fakultas Hukum Universitas Sumatera Utara : tidak diterbitkan, 2012

[17] Montez, Siti Chadijah Erna, Analisis Hukum terhadap Gadai Saham Perseroan Terbatas yang Belum Dicetak sebagai Barang Jaminan Kredit dalam Akta Notaris: Penelitian di Kota Medan, Tesis, Magister Kenotariatan Universitas Sumatera Utara Medan : tidak diterbitkan, 2003

[18] Otoritas Jasa Keuangan Republik Indonesia, Statistik 2012 dan Direktori 2013Lembaga Jasa Keuangan Lainnya, Jakarta : OJK, 2013

[19] Poeponegoro, Marwati Djoened, dan Nugroho Notosusanto, Sejarah Nasional Indonesia V: Zaman Kebangkitan Nasional dan Masa Hindia Belanda, Jakarta : Balai Pustaka, 2008

[20] Rahardjo, M. Dawam, Pembangunan Pascamodernis Esai-esai Ekonomi Politik, Yogyakarta : INSIS Press, 2012

[21] Razak, Azila Abdul, Economic and Religious Significance of the Islamic and Conventional Pawnbroking in Malaysia: Behavioural and Perception Analysis, Durham Theses : Durham University, Available at Durham E-Theses Online http://etheses.dur.ac.uk/1377/, 2011

[22] Rijawanti, Nur Indah, "Islamic Microfinance as an Alternative for Poverty Alleviation: a Survey," Afro Eurasian Studies, Vol. 2. Issue 1\&2, Spring \& Fall 2013,

[23] Supriyadi, Ahmad, "Struktur Hukum Pegadaian Syariah dalam Perspektif Hukum Islam dan Hukum Positif," EMPIRIK: Jurnal Penelitian Islam, Vol. 3, No. 2, JuliDesember 2010

[24] Susilowati, Tri Pudji, Pelaksanaan Gadai dengan Sistem Syariah di Perum Pegadaian, Tesis, Program Studi Magister Kenotariatan Program Pascasarjana Universitas Diponegoro : tidak diterbitkan, 2008

[25] Tambunan, Tulus, Usaha Mikro, Kecil, dan Menengah di Indonesia: Isu-isu Penting, Jakarta : LP3ES, 2012

[26] Wahid, Nusron, Keuangan Inklusif Membongkar Hegemoni Keuangan, (Jakarta : KPG, 2014). 